\title{
A Comparative Functionality Evaluation of Paulownia Wood Storage Boxes and Acid-free Archival Boxes to Store the Annals of Joseon Dynasty - Indoor and Outdoor Temperature and Relative Humidity Controls, and Heat Release Rate -
}

\author{
Hae Jin Park ${ }^{1}$, Seong Eun Kim¹, Jin Kyung Lee ${ }^{2}$, Yong Jae Chung ${ }^{3,}$ \\ ${ }^{I}$ Institute of Preventive Conservation for Cultural Property, Korea National University of Cultural Heritage, Buyeo 33115, Korea \\ ${ }^{2}$ Department of Conservation Science, Korea National University of Cultural Heritage, Buyeo 33115, Korea \\ ${ }^{3}$ Department of Heritage Conservation and Restoration, Graduate School of Cultural Heritage, Korea National University of \\ Cultural Heritage, Buyeo 33115, Korea
}

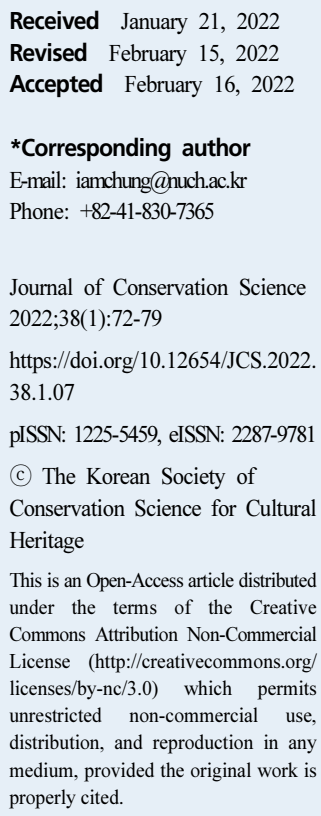

ABSTRACT A paulownia wood has been widely used with various advantages as its low weight, permeability, convenient workability and aesthetic patterns for a long time. However, the related empirical researches and simultaneous evaluations of functionality are insufficient compared with acid-free archival boxes for now. In this study, the indoor and outdoor temperature and relative humidity control and heat release rate were evaluated under the controlled and uncontrolled circumstance in 2018. The paulownia wood storage box showed superior control effect of relative humidity than the acid-free archival box in constantly uncontrolled environment. Also, the possibility of the flame diffusion from the surface of the materials was higher for the paulownia materials, and the acid-free archival box showed more dangerous patterns in the early stages of the fire.

Key Words The Annals of joseon dynasty, Paulownia wood storage box, Acid-free archival box, Temperature and relative humidity control, Heat release rate

\section{INTRODUCTION}

A storage box is widely used for handling, packing, arrangement, storage and transportation of cultural heritage materials in museums or galleries. To store the various multiple-sized books and documents together in museums and/or archives, the storage boxes should be made in an appropriate size and also be able to protect the material itself from the deterioration process caused by external environment and handling works. Among various materials, a paulownia wood has been widely used with various advantages as its low weight, permeability, convenient workability and aesthetic patterns for a long time. But, as the organic cultural properties vary in sizes and types, and the quantity is increasing, it is practically difficult to store all numbers of national treasures and general ancient books in only paulownia wood storage boxes. So, the some of general ancient books have been preserved in the acid-free archival boxes and/or put on the bookshelves to store in a storage space. 
From the Joseon Dynasty, a variety of wood materials in addition to Paulownia spp. were used to store the traditional books, ancient paintings and calligraphic works. Until now, wood materials used for the Annals of Joseon Dynasty Storage Box were found as the lime tree (Tilla spp.), pine tree (Pinus spp.) and willow tree (Salix spp.). From the previously published researches, it had been reported that these wood materials were adequate for storing and moving the several books of the Annals of Joseon Dynasty because of its low weight and high strength, permeability, convenient workability and aesthetic outlook (Park, 1982: Song and Park, 2010; Kwon et al., 2014; Kyujanggak Institute for Korean Studies, 2014; Park et al., 2017).

Meanwhile, it began to recognize the indiscriminate use and disadvantages of the paulownia wood in a field of conservation science from museums and galleries after the 1990s. It has been reported that wooden shelves and storage boxes are not suitable for permanent storage methods because they contain the resin, peroxide and formic acid, causing the damage to the traditional paper materials and archival. Also, the paulownia wood box, which has been used frequently in the storage space of the museums, is a conventional storage system using the water resistance, insect repellent and low-weight characteristics before the scientific storage environment has been advanced (Lee, 1999).

Therefore, from previously published research, we tried to verify empirically the functionality of the paulownia wood by evaluating the seasonal temperature and relative humidity control, and microbe and insect repellent activity under the controlled and uncontrolled environment. The paulownia wood showed to be mainly excellent to control the relative humidity and also buffering effect was good to adjust the average daily relative humidity range from outdoor environment. Meanwhile, it can be judged that the paulownia wood storage box cannot prevent the biological deterioration when the pest comes and attempted to attack it. Water-soluble extract from the paulownia wood produced visible zones of inhibition again five bacteria but it was difficult to predict the antimicrobial and insecticidal properties (Park et al., 2020).

The empirical researches proving its functionality were steadily requested in a field of conservation science and museology, and the simultaneous evaluations of functionality are insufficient compared with paulownia wood storage boxes and acid-free archival boxes for now. Therefore, the purpose of this study is both to evaluate the stability in uncontrolled emergency situation such as breakdown of the environmental controlling system and/or fire, and to integrate the storage management strategies for long-term preservation of the organic cultural heritages.

\section{MATERIAL AND METHOD}

\subsection{Temperature and relative humidity control monitoring}

Two comparative spaces under the controlled and uncontrolled storage conditions were investigated to identify the temperature and relative humidity control effect of the paulownia wood storage boxes and acid-free archival boxes: (1) a national storage space for the Annals of Joseon Dynasty at the Kyujanggak Institute for Korean Studies equipped with environment control system (Seoul National University, Seoul) and (2) the Korean traditional building without any thermo-hygrostate systems at the Anguk-dong detached palace (Korea National University of Cultural Heritage, Buyeo). Confirming the storage space was divided by the new and old age of air depending on the ventilation system's location and air flow at the Kyujanggak Institute for Korean Studies, the installation locations of the loggers were selected by the age of air as a indicator of ventilation properties. Each data loggers (174-H, Testo, DEU) were installed and monitored inside the paulownia wood storage box and acid-free archival box, and then recorded with 2 hours interval from 2015 to 2018 and then extracted the logged data from August to October of 2018 characterized with high daily temperature and relative humidity range (Figure 1).

\subsection{Heat release rate (Cone calorimeter method)}

The heat release rate was evaluated with paulownia wood storage box and acid-free archival box in accordance to KS F ISO 5660-1:2008 $\ulcorner$ Reaction-to-fire tests - Heat release, smoke production and mass loss rate - Part 1: Heat release rate (Cone calorimeter method)」. The measurement of heat release by Cone calorimeter is based on the oxygen 

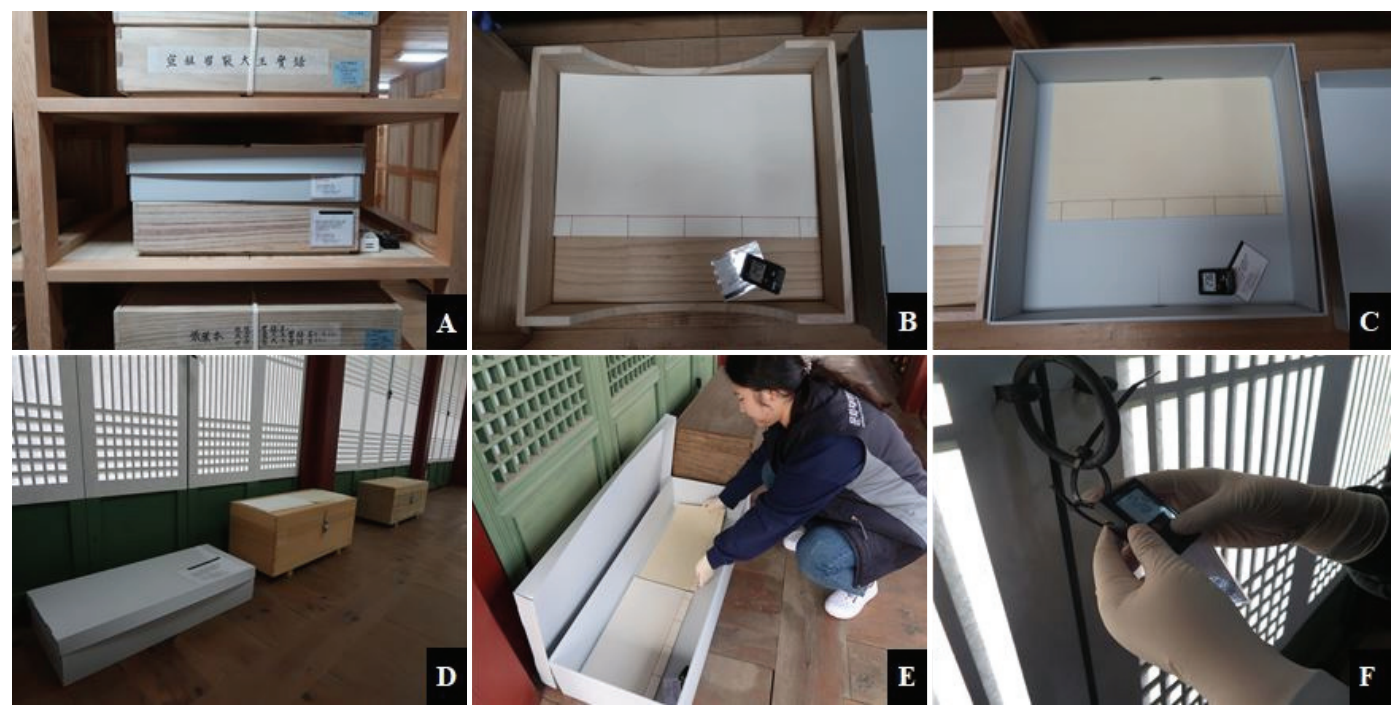

Figure 1. Indoor and outdoor storage space with loggers at the Kyujanggak Institute for Korean studies and the Anguk-dong detached palace (A, B and C: Indoor paulownia wood storage box and acid-free archival box in controlled space at the Kyujanggak Institute for Korean studies, D: Indoor paulownia and acid-free archival box in an uncontrolled space at the Anguk-dong detached palace, E and F: Outdoor paulownia and acid-free archival box in an uncontrolled space at the Anguk-dong detached palace).

consumption principle that $13.1 \mathrm{MJ}$ of the heat is released when $1 \mathrm{~kg}$ of oxygen is consumed during combustion of most organic materials. The main combustion characteristics were determined with heat release rate (HRR), time to ignition (TTI) and mass loss rate (MLR). The heating voltage condition was $50 \mathrm{~kW} / \mathrm{m}^{2}$ and heating time was 10 minutes in total with samples sized $100 \mathrm{~mm} \times 100 \mathrm{~mm}$.

\section{RESULT AND DISCUSSION}

\subsection{Temperature and relative humidity control monitoring}

Monthly average temperature between new and old age of air in a controlled storage space at the Kyujanggak Institute for Korean Studies was measured from $20.8^{\circ} \mathrm{C}$ to $21.0^{\circ} \mathrm{C}$. The

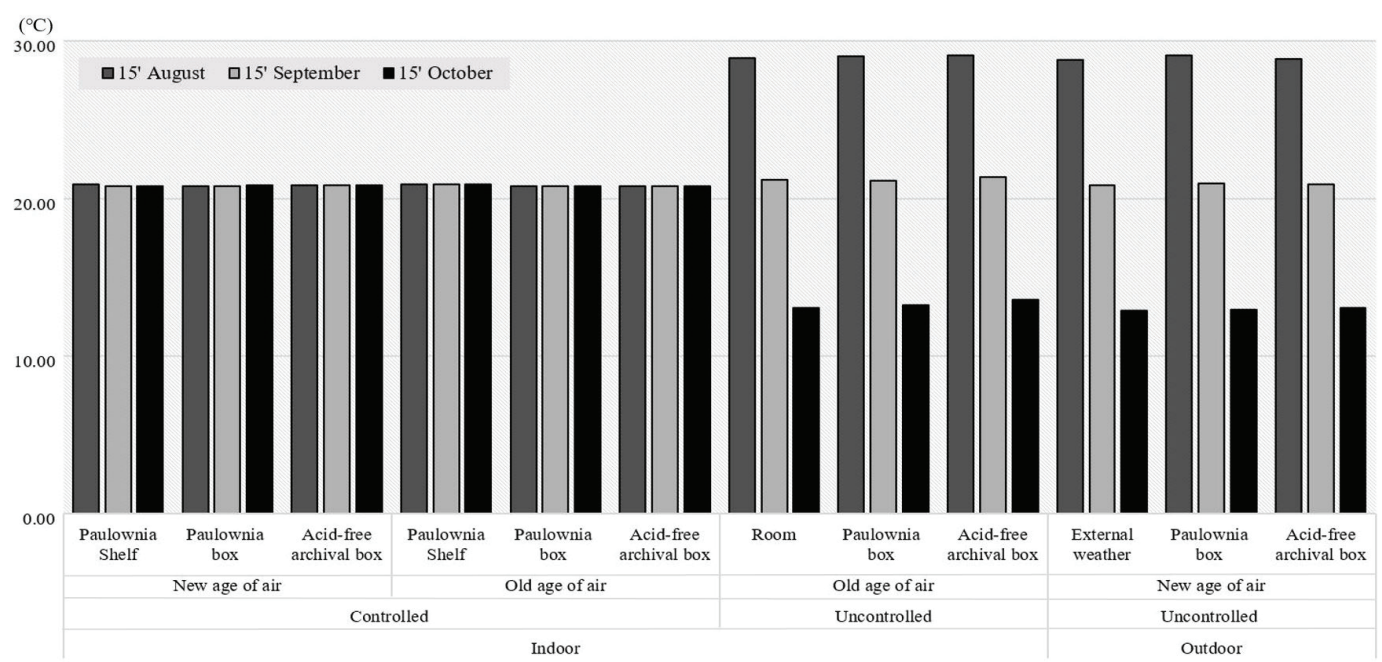

Figure 2. Monthly average temperature of paulownia box and acid-free archival box $\left({ }^{\circ} \mathrm{C}\right)$. 
temperature range inside the paulownia storage box under the new and old age of air ranged from minimum $20.8^{\circ} \mathrm{C}$ to maximum $21.0^{\circ} \mathrm{C}$ so that there was the difference of $0.2^{\circ} \mathrm{C}$. Compared to the monthly average temperature of paulownia storage box, the acid-free archival box showed the difference of $0.1^{\circ} \mathrm{C}$. Measuring the monthly average temperature of uncontrolled storage space at the Anguk-dong detached palace from August to October of 2018, the temperature was decreasing toward to October. However, the difference of monthly average temperature depending on the installation location at the Anguk-dong detached palace was not significant compared to external weather condition (Figure 2).

Investigating the change of the monthly average relative humidity from the constantly controlled storage space from August to October of 2018, the paulownia storage box with good ventilation location was the highest at $66.6 \%$ on August and the lowest of acid-free archival box was measured to $61.09 \%$ with new age of air on October under the controlled environment. The monthly average relative humidity of external weather on October from the uncontrolled traditional building was $80.1 \%$; and those of indoor paulownia wood storage box and acid-free archival box were $69.3 \%$ and $69.95 \%$ while those of outdoor paulownia wood storage box and acid-free archival box were $67.8 \%$ and $67.4 \%$. This result indicates that paulownia wood storage box and acid-free archival box, installed inside a room of an uncontrolled space

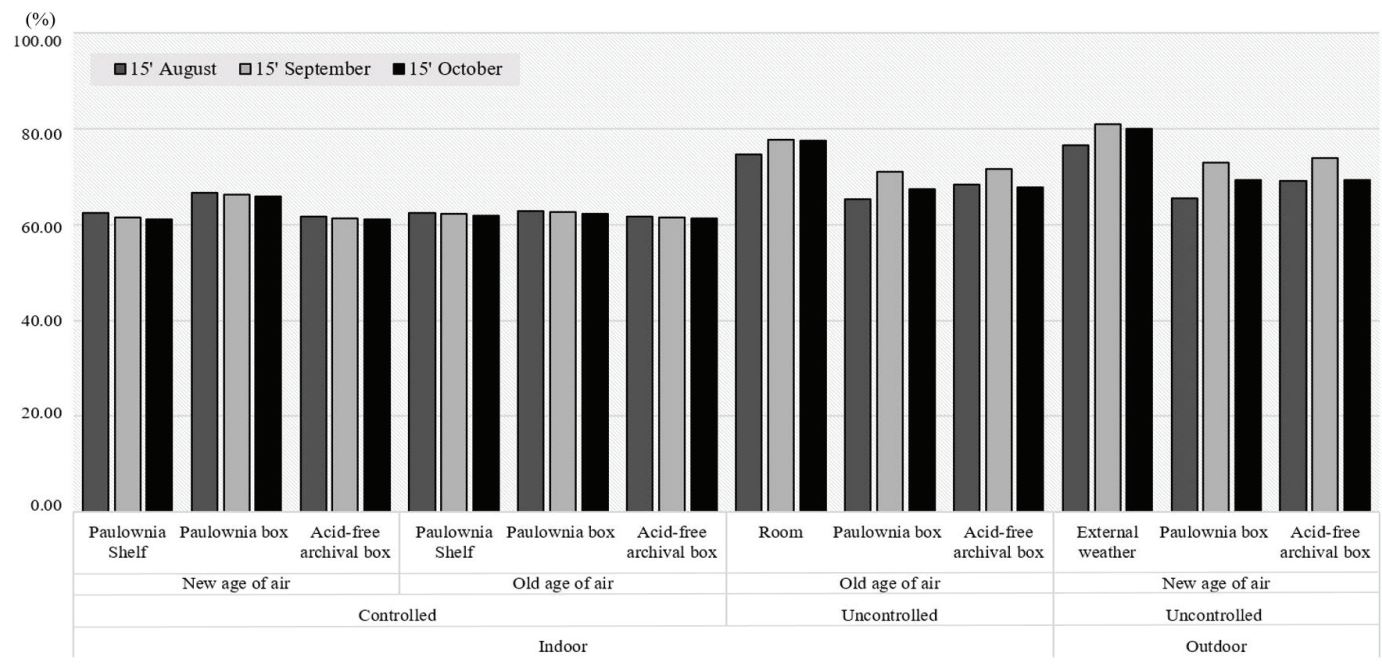

Figure 3. Monthly average relative humidity of paulownia box and acid-free archival box (\%).

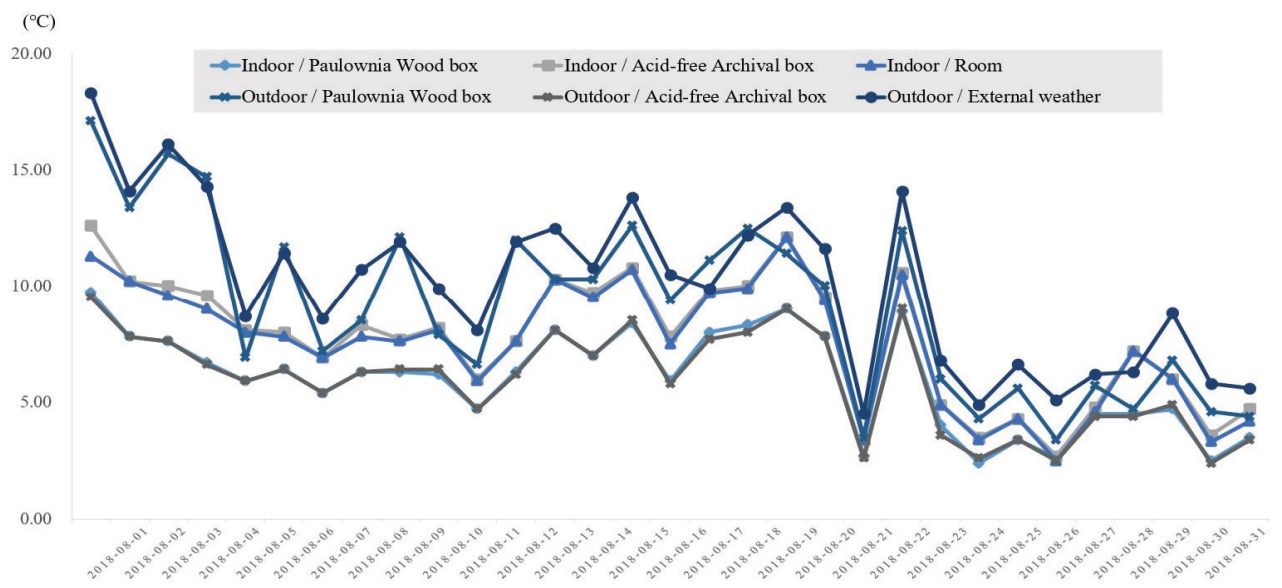

Figure 4. Daily average temperature range of paulownia box and acid-free archival box located in uncontrolled storage space on August of $2018\left({ }^{\circ} \mathrm{C}\right)$. 
at the Anguk-dong detached palace, showed better relative humidity buffering effects than those installed and exposed to unstable outside weather environment during early fall-season (Figure 3).

The daily change range was clear on August (early-fall season) and the change in the daily temperature range under uncontrolled circumstance was greater in order of external weather, outdoor paulownia wood storage box, indoor room, outdoor acid-free archival box, indoor paulownia wood storage box and acid-free archival box. Then, the range of change in the daily relative humidity was greater in order of external weather, outdoor acid-free archival box, indoor room, outdoor paulownia wood storage box, indoor acid-free archival box and paulownia wood storage box (Figure 4 and 5).

Considering the difference of the monthly average relative humidity range depending on the installation location and storage circumstance, the difference was calculated by subtracting the monthly average relative humidity range of external weather to those of measured values by installation condition and storage materials. The difference of monthly average relative humidity range was reduced to $75.46 \%$ for the paulownia wood storage box and $64.78 \%$ for the acid-free archival box stored in outdoor environment compared to that of the external weather from August to October of 2018. The

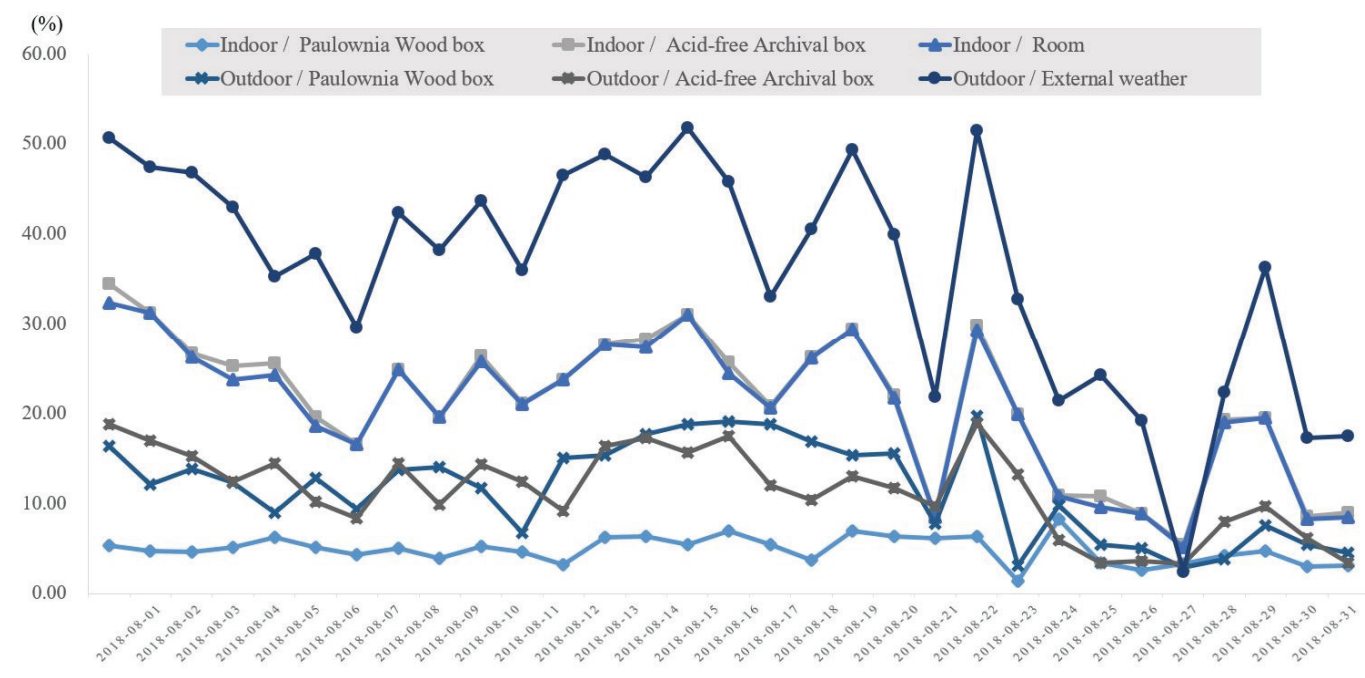

Figure 5. Daily average relative humidity range of paulownia box and acid-free archival box located in uncontrolled storage space on August of $2018(\%)$.

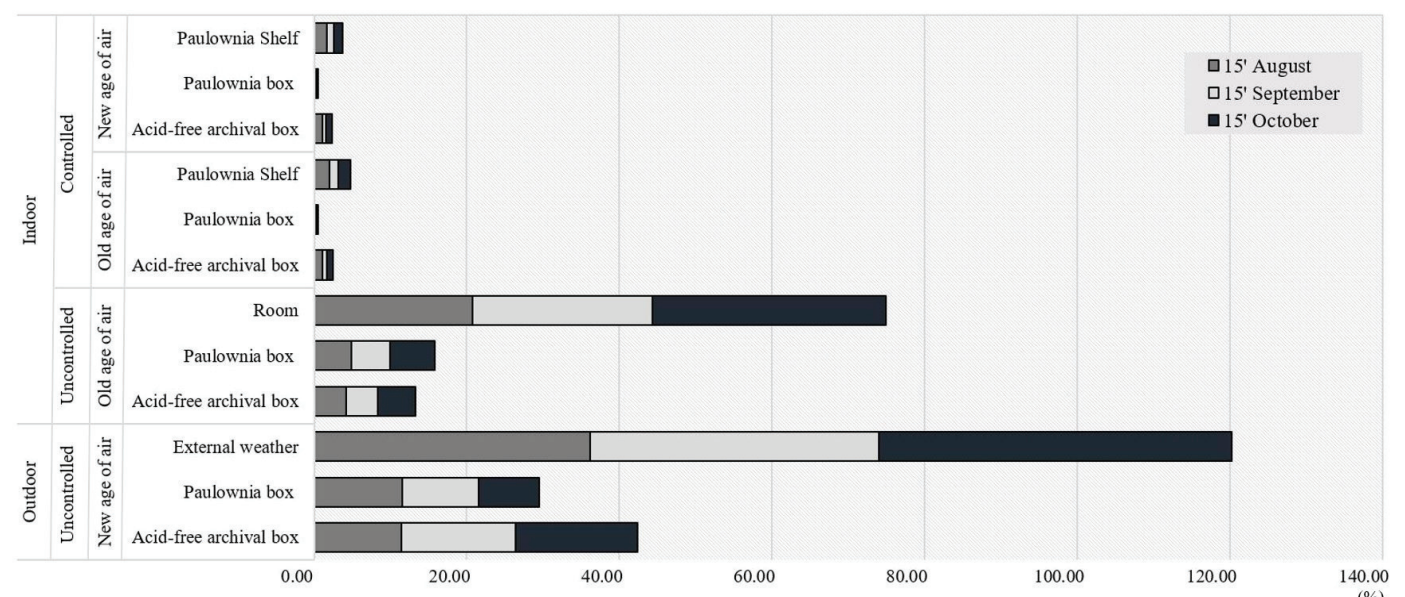

Figure 6. Monthly average relative humidity range of paulownia box and acid-free archival box (\%). 
Table 1. The result of the heat release rate for the paulownia box and acid-free archival box

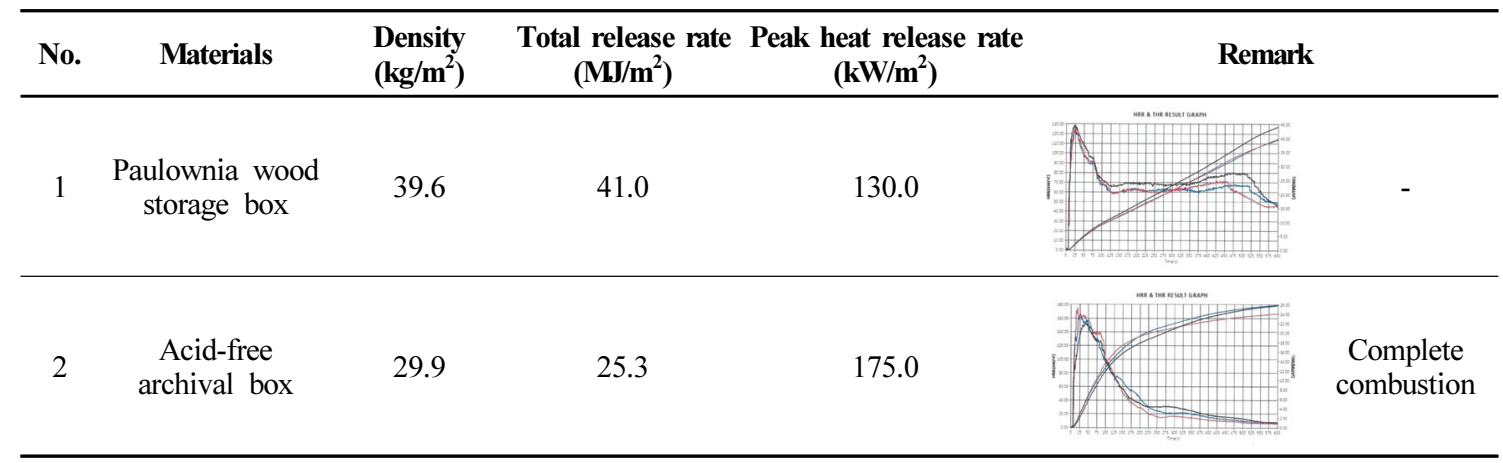

paulownia wood storage box and acid-free archival box, stored in a traditional architecture where the constant temperature and relative humidity has not been controlled, showed the control effect to buffer the $86.83 \%$ and $88.91 \%$ of the monthly average relative humidity range from the external weather. Under the constant storage space at the Kyujanggak Institute for Korean Studies where the adequate temperature and relative humidity kept constantly, the standard values of monthly average relative humidity range were set to the ranges of the paulownia shelf with new and old age of air; the difference of buffering effect with paulownia wood storage box and acid-free archival box was also confirmed under the indoor conditions with both new and old age of air; and the buffering effect of the paulownia wood storage box was slightly superior to that of the acid-free archival box in indoor controlled space (Figure 6).

\subsection{Heat release rate (Cone calorimeter method)}

The total release rate (THR) is the sum of the calories of the heat generated on the surface of the specimens during combustion and also it can be a risk value that allows us to understand the possibility of the fire risk and flame spread from the surface of the material itself. Cone calorimeter method was able to evaluate the decomposition characteristics and the change of heat quantity over time. The THR of the paulownia wood storage box was $41.0 \mathrm{MJ} / \mathrm{m}^{2}$, and that of the acid-free archival box was measured to $25.3 \mathrm{MJ} / \mathrm{m}^{2}$; THR of the paulownia wood storage box was higher than that of the acid-free archival box. Nevertheless, the peak heat release rate of the acid-free archival box was greater to $175.0 \mathrm{~kW} / \mathrm{m}^{2}$ while that of the paulownia wood storage box was measured to $130.0 \mathrm{~kW} / \mathrm{m}^{2}$. This results indicates that the acid-free archival box is more dangerous in the early stage of the fire than paulownia materials (Table 1).

\subsection{Integrated storage management strategy}

The results of Table 2 in this research and the previously published research were comprehensively interpreted to suggest the integrated storage management strategy for a long-term preservation of the cultural heritage (Park et al., 2020). Through the temperature and relative humidity control evaluation, it was proved that both paulownia wood storage box and acid-free archival box were effective in relative humidity control in an environment where the stable temperature and relative humidity conditions were not controlled. Nevertheless, the relative humidity control effect of the paulownia wood storage box was superior than that of the acid-free archival box. It was possible to confirm the buffering effect of relative humidity according to the materials used for the storage box in the event of an emergency where temperature and relative humidity cannot be controlled automatically.

According to the previously published research of the microbe and insect repellent activity, paulownia wood storage box did not have insect and microbe repellent substances and/or antifungal and antibacterial substances toward to 9 different types of microbe collected in a controlled storage space at the Kyujanggak Institute for Korean Studies. In the water-soluble extract of paulownia wood material, it had a weak antibacterial activity against 5 types of bacteria collected from the storage space at the Kyujanggak Institute for Korean Studies. However, it could not prevent the 
Table 2. The results of comparative functionality and integrated storage management strategy ( $\bigcirc$ : Excellent, $\triangle$ : Middle, $\nabla:$ Low, $\times$ : None)

\begin{tabular}{|c|c|c|c|}
\hline No. & Materials & Paulownia wood storage box & Acid-free archival box \\
\hline 1 & $\begin{array}{c}\text { Relative } \\
\text { humidity control }\end{array}$ & $\begin{array}{l}\qquad[\circ] \\
\text { - Based on percentages of the monthly average } \\
\text { relative humidity range of external weather } \\
(100 \%) \text {, the uncontrolled outdoor paulownia } \\
\text { box reduced } 75.46 \% \text { of the monthly average } \\
\text { relative humidity range and uncontrolled } \\
\text { indoor paulownia box buffered } 86.83 \% \text { of } \\
\text { the monthly average range from external } \\
\text { weather. }\end{array}$ & $\begin{array}{l}\text { - Based on percentages of the monthly } \\
\text { average relative humidity range of external } \\
\text { weather }(100 \%) \text {, the uncontrolled outdoor } \\
\text { acid-free archival box reduced } 64.78 \% \text { of } \\
\text { the monthly average relative humidity } \\
\text { range and uncontrolled indoor acid-free } \\
\text { archival box buffered } 88.91 \% \text { of the } \\
\text { monthly average range toward from } \\
\text { external weather. }\end{array}$ \\
\hline 2 & $\begin{array}{l}\text { Microbe and } \\
\text { insect repellent } \\
\text { activity }\end{array}$ & $\begin{array}{l}\qquad[\nabla] \\
\text { - Not having the insect and microbe repellent } \\
\text { substances, and antifungal and antibacterial } \\
\text { substances toward to } 9 \text { different types of } \\
\text { microbe. } \\
\text { - Volatile extracts not affecting the growth } \\
\text { of fungi and bacteria. } \\
\text { - Water-soluble extracts with weak } \\
\text { antibacterial activity }\end{array}$ & - \\
\hline 3 & $\begin{array}{l}\text { Heat } \\
\text { release rate }\end{array}$ & $\begin{array}{l}\text { - Total heat release rate: } 41.0 \mathrm{MJ} / \mathrm{m}^{2} \\
\text { - Peak heat release rate: } 130.0 \mathrm{~kW} / \mathrm{m}^{2}\end{array}$ & $\begin{array}{l}\text { - Total heat release rate: } 25.3 \mathrm{MJ} / \mathrm{m}^{2} \\
\text { - Peak heat release rate: } 175.0 \mathrm{~kW} / \mathrm{m}^{2} \\
\text { - Completely burned }\end{array}$ \\
\hline
\end{tabular}

biological deterioration when the pest attempted to attack it and also it was difficult to expect the any antibacterial effect as one of the storage items used in the field of storage management (Park et al., 2020). Following another published research, it coincides that the paulownia storage box material was not good enough for antimicrobial property despite its customary use (Chung et al., 2008). In the evaluation of heat release rate, the acid-free archival box is more dangerous in the early stage of the fire. After the evaluation, the acid-free archival box was completely burned.

For the purpose to control the relative humidity for the organic cultural properties as national treasures and/or treasures with the importances and their meaning, it is recommended to keep and preserve them inside the paulownia wood storage boxes while general old books, ancient paintings and calligraphic works can be stored in the acid-free archival box as they also have the ability to control the relative humidity.

Paulownia is known well as peculiar characteristics such as low weight but not suitable for the purpose to store heavy books. However, when the emergency situation that the central air conditioner does not operate and/or the ancient books are needed to moved due to a disaster, it is judged that paulownia wood material has an advantage due to sealing-tightness, relative humidity control effect, and light properties for emergency movement and/or handling.

The acid-free archival box is very stable storage materials when stored in a storage space under the constant temperature and relative humidity conditions; but while it can be exposed for long-term period under the external changing conditions, the deformation can be made and very fine dust and/or other contaminants may enter into the inner space through the deformed lid of the archival box. Therefore, it is recommended to be applied for storage in a stable storage room with constant controlled conditions.

\section{CONCLUSION}

The storage boxes are the products used to arrange and store the traditional books, ancient paintings and calligraphic works, and it should be made in an appropriate size accordingly to the shapes and characteristics of them. They should be able to protect and preserve the organic materials from the deterioration process caused by the external environmental factors and/or artificial damage from handling. Also, the storage boxes should not emit any formaldehyde 
and also should be kept in adequate conditions with sufficient mechanical strength for a long-term period.

In Korea, wooden storage boxes have traditionally been used to preserve and manage the ancient books; and in particular, paulownia is widely used as one of the materials for storage box and shelf as an interior of storage and exhibition space in museums because of its light-weight and ease of humidity control. And the acid-free archival box is made of corrugate cardboard for outer packing and cushioning function. As the organic cultural properties vary in sizes and types, and the quantity is increasing, it is practically difficult to store all numbers of national treasures and general ancient books in only paulownia wood storage boxes, so the some of them have been put in the acid-free archival boxes together. In this study, it was conducted both to evaluate the stability in uncontrolled emergency situation such as breakdown of the environmental controlling system or fire, and to integrate the storage management strategies for long-term preservation of the organic cultural heritages.

Through the evaluation of temperature and relative humidity control effect, both paulownia wood storage box and acid-free archival box were effective in controlling and buffering the relative humidity in an environment where the temperature and relative humidity conditions have been not controlled constantly. Meanwhile, the paulownia wood storage box showed superior control effect of relative humidity than the acid-free archival box. Therefore, it was possible to confirm the relative humidity control ability depending on the materials used for the storage box in an emergency situation where it is suddenly difficult to control the constant temperature and relative humidity.

The possibility of the flame diffusion from the surface of the materials was seriously higher for the paulownia materials, and the acid-free archival box showed more dangerous patterns in the early stages of the fire. It was possible to evaluate the decomposition and calorie changes over time, it can be used as an index to evaluate the risk of the fire with storage materials in the future. Based on the results of this study, it is expected that it can be applied to make the emergency manuals for the long-term preservation of organic cultural properties such as the Annals of the Joseon Dynasty and the other generous ancient books in near future.

\section{ACKNOWLEDGMENTS}

This study was conducted as a part of "Research on Conservation Environment Assessment and Management System Establishment for Conserving Annals of Joseon Dynasty (2015-2018)" and we would like to especially thank the support of Kyujanggak Institute for Korean Studies.

\section{REFERENCES}

Chung, Y.J., Kang, S.Y. and Choi, Y.A., 2008, Analysis on antifungal activity of paulownia-wood storage box and application of natural biocide for the activity enhancement. Journal of Conservation Science, 24, 75-83. (in Korean with English abstract)

Kwon, Y.H., Lee, S.A., Kim, H.J. and Lee, T.Y., 2014, The trees that make money. Green Happiness, Seoul, 356-360. (in Korean)

Kyujanggak Institute for Korean Studies, 2014, New born Joseon recording culture: white paper on repair and restoration management of cultural property in Kyujanggak. 118-112. (in Korean)

Lee, Y.S., 1999, How to preserve old documents permanently: especially papers. Journal of Korean Library and Information Science Society, 30(1), 243-256. (in Korean with English abstract)

Park, H.J., Jeong, S.H., Lee, H.J., Lee, N.R. and Chung, Y.J., 2020, A Paulownia coreana box for storage of Annals of Joseon Dynasty: its efficacy and functionality evaluations of temperature and relative humidity control, and microbe and insect repellent activity. Journal of Conservation Science, 36(4), 255-263. (in English)

Park, S.Z., Jung, D.U. and Yi, Y.H., 2017, Material analysis and conservation treatment of the Annals of Joseon Dynasty storage box. Journal of Conservation Science, 33(1), 17-24. (in Korean with English abstract)

Park, Y.K., 1982, Korean wood furniture. Samsung Publishing, Seoul, 9-10. (in Korean with English abstract)

Song, J.A. and Park, W.K., 2010, Species of Korean furniture in the late Choseon Dynasty (I). Journal of the Korea Furniture Society, 21(6), 486-498. (in English with Korean abstract) 